\title{
MARKET AND FINANCIAL FEASIBILITY ANALYSIS: A CASE STUDY ON "PONDOK MARANGGI 17” RESTAURANT
}

\author{
Salamin Petrus Pius*, Hermawan Francisca, Setiawan Kevin \\ Faculty of Economy and Business, Atma Jaya Catholic University of Indonesia \\ ${ }^{*}$ E-mail: petrus.salamin@atmajaya.ac.id
}

\begin{abstract}
PondokMaranggi 17 is the name of a new restaurant established in the year of 2017, located in Bekasi. The main menu of this restaurant is "Sate Maranggi". The vision of this restaurant is to be the first choice for those who like Sate Maranggi, especially for those who live in region of Bekasi. In order to achieve this vision, PondokMaranggi 17 has to create the best quality and special taste of food and beverage. This business needs start-up capital amounting to Rp 223.454.600. Projected net profit in 2018 is Rp 91.276.960, and it will increase with average growth of $46.4 \%$ per year. The financial feasibility from the point of view Net Present Value, Payback Period, Average Rate of Return, and Profitability Index of this business is very feasible.
\end{abstract}

\section{KEY WORDS}

Business, restaurant, market, profit, growth.

PondokMaranggi 17 is the name of the Sundanfood restaurant began operating in March 2017. It is located in an area Jatirasa/Jatiasih, Bekasi, West Java. ThisSudantraditional nuance restorant with a modern concept, accentuates "sate maranggi" (maranggy satay) as the main food or menu. This restaurant, as well as, provides some alternative menu options according to the taste of consumers, such as steam coconut milk rice (nasiuduk), grilled chicken, catfish dish (pecellele), and chicken skin satay.PondokMaranggi 17 using good quality raw materials, to ensure that the best qualitytaste of food can be achieved. In addition the chilishrimp paste and chili sauce, varations of drinks and good services to be the part of the strategies of PondokMaranggi 17 to make this business success. Furthermore, this Sundan nuance restaurant can be one of the culinary tourism destination forthe societies of Bekasi and surrounding areas, especially on weekends and holidays.

The vision of PondokMaranggi 17 isbecoming arestaurantfavouredby consumers, capable of mastering the markets, and making a profit, as well as being able to maintain the survival of the business.

To achieve these goal and vision, PondokMaranggi will produce excellent quality food, provides various variants of food and beverages, according to the consumers taste, with maranngi satay as its icon. In addition, the room will be arranged in such a way so that consumers can feel comfortable, relax, so happy to be there. PondokMaranggi 17 will also initiate the best service systemfor the sake of consumers' satisfaction.

The main purpose of this business is to gain profit. However, the profit is just the rewardsreceived, having the business satisfied what the consumers'needs and desires, which make their life better off. Therefore, PondokMaranggi 17 will put the needs and wants of the consumers being the most important thing in the whole of its business strategies. This article is concern with theanalyzing of themarket and financial feasibility of PondokMaranggi 17.

The data used, in particular the price, is the primary data of the survey results, and it is the current price in the market at that time. The method of determining the level of the market potential is based on qualitative analysis of current market conditions. Whereas, the level of sales is determined based on the capacity of the restaurant, taking into account the market potential at this time and in the future, as well as the selling price which is considered reasonable in the area surrounding the location. Financial feasibility is measured using the 
method of Net Present Value (NPV), Payback Period, the Average Rate of Return (ARR), and Profitability Index (PI).

\section{LITERATURE REVIEW}

Reviews of the literature in this writing includes three major things, namely, market opportunities and market strategies, financial statements, and financial feasibility of the business. Here's the short explanation.

Markets opportunities. To find out how the market opportunity for a new product or a new business, first to be analyzed is its market target. Then, setting the product or business positioning in the the market or among other competitors. Furthermore, analyzing the potential demand for these products, either by using the method of consultation with the experts, the methods of experimental test/survey methods, statistical methods (Regression and Correlation, Time Series), as well as methods of Input Output (SuadHusnan, 2016). Then, by consideration of factors that potenciallywill affect the business, hence sales plan for the future is set. The sales plan had been set, it is not automatically can be achieved, but it needs to be supported by an appropriate marketing strategy. This marketing strategy consists of product strategy, pricing strategy, placestrategy and promotion strategy (Scarborough, 2016). The combination of these four marketing strategies in marketing literature commonly referred to as the Marketing Mix.

Financial Report. There are three (3) basic financial reports i.e. balance sheet, income statement and cash flow statement. Seen from the time of occurrence of the financial transaction, there are two kinds of financial statements, namely the Historical Financial Statements and Pro Forma Financial Statements (Scarborough, 2016). Historical Financial Statements are financial statements that are based on financial transactions that have occurred in the past. Meanwhile, the Pro Forma Financial statements are financial statements that are based on transactions that will occur in the future. In other words, Pro Forma Financial Statements is a projection or a financial plan for the future.

Business Feasibility Analysis. To measure the feasibility of financial aspects is usually used what is referred to as a criterion of investment (investment criterions). There are five methods commonly used to assess the financial feasibility of an investment, they are the Average Rate of Return, the Net Present Value (NPV), Payback Period, Internal Rate of Return (IRR), and Profitability Index (SuadHusnan, 2016).

Market Feasibility Analysis. The intended target market puts emphasis more on the lower-middle-class, which is the majority groups living around the site where the business was established. The target market is not only the resident living in the vicinity of housing complex, but also the office workers and factory laborers nearby. Pricing strategies etc., therefore, are devoted especially to reach the lower-middle-class indeed. In line with the above target market, PondokMaranggi 17 wants to be known as a restorant which has a distinctive flavor of maranggi satay compared to the same other restaurants, affordable prices, and comfortable and clean place to enjoy food. This is the positioning wanted in the market.

Quoted from http://www.antarnews.com March4 ${ }^{\text {th }} 2017$, food and beverage industry would be the trigger for growth in non-oil and gas processing industry in the year of 2017, which is targeted to grow $5.3-5.6$ percent. Furthermore, the Government stated that the food and beverage sector is projected to grow 7.5-7.8 percent in 2017. In line with that, quoted from suara.com March $4^{\text {th }} 2017$, food and beverage industry have an important role in economic growth and have a great contribution towards the gross domestic product (GDP) in Indonesia, and food and beverages industry sectors account for 31.20 percent of the GDP. This sector, therefore, is to be one of the prioritysectors, stated by the Government, in encouraging the industrial development as a driving force for the national economic growth.

From a short blurb above it can be concluded that the food and beverage industry is a high-growth industry.For entrepreneurs, this condition,they see it as a business opportunity in the field of food and drink, including restaurant. 
The famous maranggi satay is in Purwakarta, West Java. Outside Purwakarta, vendor or restaurant maranggi satayis very rare. There are a few widespread restaurants that sold meat maranggi, but in general, it is out of reach of potensialcosumers. In the region of Bekasi itself, where the site of PodokMaranggi 17 is, there are no competitors that sell maranggi satay. So, definitely there is no direct competitors. There are, however, indirect competitors, that isother types of satay seller, such as chicken satay, goat satay or other kinds of foods that provide an alternative choice to the consumers. The absence of direct competitors, giving the greater possibility toPondokMaranggi 17 to be successful.

Furthermore, modern lifestyle in which many people or families are no longer they cook their food by themselves, but eating outside the home or in the restaurantor food stalls. Many people tend to choose more practical, quick and no hassle ways to get food, rather than cook it by themselves. In addition, the workers especially in the daytime will choose to eat at the restaurant or food stalls, fortheir office is far from home. It is the same with the young single workers, they tend to choose to eat outside the home, either becausethey don't have enough time to cook, or have no skills to cook food. In addition, the emergence of life style trend inwhich the culinary has become an object of tourism (culinary tourism) and entertainment, especially on a weekends where families enjoy eating out of the home.

The prospective potencial comsumers for PondokMaranggi is also supported by its strategic location, being in the office or business and industrial area, as well as not far from the housing complex.

Having regard to the factors that affect sales, such as market opportunity put forth above, capacity of this restaurant, 5 years development plan forward, an increasing number of consumers/customers, as well as rising prices and rising costs, then PondokMaranggi 17 projecting its sales as shown in table 1 below:

Table 1 - Sales Projections (2017-2021)

\begin{tabular}{|c|c|c|c|c|c|}
\hline Description & 2017 & 2018 & 2019 & 2020 & 2021 \\
\hline $\begin{array}{c}\text { The value of } \\
\text { purchase / } \\
\text { consumer }\end{array}$ & Rp20.000 & Rp20.000 & Rp25.000 & Rp25.000 & Rp30.000 \\
\hline $\begin{array}{c}\text { Prospective } \\
\text { Consumer }\end{array}$ & 27.000 & 29.700 & 32.670 & 35.937 & 39.530 \\
\hline Sales & Rp540.000.000 & Rp594.000.000 & Rp816.750.000 & Rp898.425.000 & Rp1.185.900.000 \\
\hline
\end{tabular}

Source: processed data.

Note:

Sales target above is calculated with the assumptions/projections are as follows:

a. Restaurant capacity restaurant (seats available) 50. Open hours: 10.00-22.00 hours $=12$ hours

b. Average long of stay per consumers = 2 hours; so one seat in 1 day will be used $12 / 2=6 \mathrm{x} / \mathrm{seat} / \mathrm{person}$

for 50 seats $=50 \times 6=300$ person/days (full capacity); Full Capacity for 1 year $=300 \times 300$ (days) $=90,000$

c. Projected to be $30 \%$ filled, 50 (30\% x $300=90$ person/days; In a year (300 days): $(300 \times 90=27,000$ people/year

d. Every two years the price will be increased amounting to $R p 5,000$

e. Increase of visitors is about $10 \%$, from the previous year.

Marketing Strategy. In achieving the sales targets above, PondokMaranggi 17 will apply marketing mix strategy including product strategy, pricing strategy, place/distribution strategy and promotion strategy.

Product or the main menu which become an icon of the PondokMaranggi 17 is maranggi satay, with a special taste. However, Pondok Maranggi17 restaurant also provides various types of other foods and a variety of drinks, giving an alternative choice to the taste of the consumers. The menu variety provided will be evaluated periodically, whether to be maintained or to be leaved, without leaving the main menu i.e. maranggi satay.

Pricing strategy applied is low prices; this means that PondokMaranggi 17 will not take a high margin profit. This strategy is in line with the purchasing power of the majority of prospective consumers or its target market, which is lower-middle-class.

The selected location at Bekasi is in the area of business and industry, and it is close to housing residents. So, it is expectedthat this restaurant would have adequate prospective 
consumers. This site is expected to be one of the competitive advantages of PondokMaranggi 17.

Podok Maranggi 17 restaurant was established recently; it is not known to many people yet, then promotion on social media must be agressive, banners and brochures are distributed widespread primarily in the area surrounding the location and Bekasi in general.

From the market opportunities described above it can be concluded that this business has a potential possibility to be success, and it is, therefore, feasible.

Financial Feasibility Analysis. A projection or a financial plan for the establishment of Pondok Maranggi 17 restaurants includes the start-up capital, source of funding, initial Balance Sheet, and Pro Forma Income Statement.

The start-up capital needed is Rp. 223.454.600. This consists of investment in fixed assets amounting to Rp 101.229.600, and working capital amounting to Rp. 122.225.000. Details of the start-up capital needed and its use can be seen in table 2 below:

Table 2 - The Need and Use of Funds

\begin{tabular}{|l|l|}
\hline \multicolumn{1}{|c|}{ Description } & \multicolumn{1}{c|}{ Total } \\
\hline Fixed Assets: & $\operatorname{Rp~98.639.200}$ \\
\hline Fixed Asset (depreciated in 5 years) & $\operatorname{Rp~2.590.400}$ \\
Equipment (eprciated in 2 years) & $\operatorname{Rp~} 101.229 .600$ \\
Total Fix Asset & \\
Working Capital, used for: & $\operatorname{Rp~50.000.000}$ \\
Rent Place & $\operatorname{Rp~5.355.000}$ \\
Raw Material (1x production/day) & $\operatorname{Rp~} 16.870 .000$ \\
General and Administration & $\operatorname{Rp~50.000.000}$ \\
Cash money supply & $\operatorname{Rp~122.225.000}$ \\
\hline Total Working Capital & $\operatorname{Rp~223.454.600}$ \\
\hline Total Funding Needs & \\
\hline
\end{tabular}

Source: processed data.

Source of funding is from the owner itself, amounting Rp 223.454.600 (owners capital).

From the profit Projections in table 5 below, it is shown that the net profit of the PondokMaranggi 17 increases from Rp 91,276,960 in the year 2017, to Rp 358,588,290 in 2021 , with an average growth of $46.4 \%$ per year.

Table 3 - Pro Forma Income Statement of PondokMaranggi 17, 2017-2021

\begin{tabular}{|c|c|c|c|c|c|}
\hline Description & 2017 & 2018 & 2019 & 2020 & 2021 \\
\hline Sales & 540.000 .000 & 594.000 .000 & 816.750 .000 & 898.425 .000 & 1.185 .900 .000 \\
\hline $\begin{array}{l}\text { Expenses: } \\
\text { COGS (raw material, etc) }-40 \% \text { of sales }\end{array}$ & 216.000 .000 & 237.600 .000 & 326.700 .000 & 359.370 .000 & 474.360 .000 \\
\hline Gross Profit & 324.000 .000 & 356.400 .000 & 490.050 .000 & 539.055 .000 & 711.540000 \\
\hline $\begin{array}{l}\text { 2. Depreciation: } \\
\text { - Fix Asset } \\
\text { - Equipment }\end{array}$ & $\begin{array}{l}19.727 .840 \\
1.295 .200 \\
21.023 .040 \\
\end{array}$ & $\begin{array}{l}19.727 .840 \\
1.295 .200 \\
21.023 .040 \\
\end{array}$ & $\begin{array}{l}19.727 .840 \\
1.295 .200 \\
21.023 .040 \\
\end{array}$ & $\begin{array}{l}19.727 .840 \\
1.295 .200 \\
21.023 .040 \\
\end{array}$ & $\begin{array}{l}19.727 .840 \\
1.295 .200 \\
21.023 .040 \\
\end{array}$ \\
\hline $\begin{array}{l}\text { 3. General \& Adm. Expense: } \\
\text {-Employee Salaries } \\
\text {-Owner Salaries } \\
\text {-Electricity \& water } \\
\text {-Hygiene } \\
\text {-Rent } \\
\text {-Advertisement Tax }\end{array}$ & $\begin{array}{l}96.000 .000 \\
36.000 .000 \\
21.700 .000 \\
600.000 \\
50.000 .000 \\
2.000 .000 \\
\end{array}$ & $\begin{array}{l}105.600 .000 \\
39.600 .000 \\
23.870 .000 \\
900.000 \\
60.000 .000 \\
2.000 .000 \\
\end{array}$ & $\begin{array}{l}116.160 .000 \\
43.560 .000 \\
26.257 .000 \\
1.350 .000 \\
70.000 .000 \\
2.000 .000 \\
\end{array}$ & $\begin{array}{l}127.776 .000 \\
47.916 .000 \\
28.882 .700 \\
2.025 .000 \\
80.000 .000 \\
2.000 .000 \\
\end{array}$ & $\begin{array}{l}140.553 .600 \\
52.707 .600 \\
31.770 .970 \\
3.037 .500 \\
90.000 .000 \\
2.000 .000 \\
\end{array}$ \\
\hline Total expense $(2+3)$ & 227.323 .040 & 252.993 .040 & 280.350 .040 & 309.622 .740 & 341.092 .710 \\
\hline Earning before tax & 96.676 .960 & 103.406 .960 & 209.699 .960 & 229.432 .260 & 370.447 .290 \\
\hline $\operatorname{Tax} 1 \%$ & 5.400 .000 & 5.940 .000 & 8.167 .500 & 8.984 .250 & 11.859 .000 \\
\hline Earning after tax (EAT) & 91.276 .960 & 97.466 .960 & 201.532 .460 & 220.448 .010 & 358.588 .290 \\
\hline
\end{tabular}

Source: processed data.

Here, the financial feasibility of Pondok Maranggi 17, can be measured by using the the method of Net Present Value (NPV), Payback Period, Average Rate of Return, and Profitability Index. Business Net Cash Flow and Present Value per year can be shown in 
Table 6 (Present value work sheet) below:

Table 4 - The Present Value Work Sheet

\begin{tabular}{|l|l|l|l|l|l|l|}
\hline Description & To & T1, 2017 & T2,2018 & T3,2019 & T4,2020 & T5,2021 \\
\hline Earning after tax & & 91.276 .960 & 97.466 .960 & 201.532 .460 & 220.448 .010 & 358.588 .290 \\
\hline Total fixed asset depreciation & & 21.023 .040 & 21.023 .040 & 21.023 .040 & 21.023 .040 & 21.023 .040 \\
\hline Operasional cash flow & & 112.300 .000 & 118.490 .000 & 222.555 .500 & 241.471 .050 & 379.611 .330 \\
\hline $\begin{array}{l}\text { Investment: } \\
\text { - Fixed Asset } \\
\text {-Working Capital }\end{array}$ & $(101.229 .600)$ & - & & & & \\
& $(122.225 .000)$ & - & - & - & & \\
Net Cash flow & $(223.454 .600)$ & 112.300 .000 & $118.490 .400)$ & & - & \\
\hline Discount Factor (10\%) & 1 & 0.909 & 0.826 & 219.965 .100 & 241.471 .050 & 379.611 .330 \\
\hline PV & $(223.454 .600)$ & 102.080 .700 & 97.873 .236 & 165.193 .790 & 164.924 .727 & 235.738 .640 \\
\hline
\end{tabular}

Source: processed data.

Note: Terminal Cash Flow (Fixed Assets and Working Capital) is not included in the above Net Cash Flow, because this business will still continue on, it dasnot close down at the end of the year 2021.

Thus, the financial feasibility of PondokMaranggi 17 can be calculated as follows:

1. $\mathrm{NPV}=(223.454 .600)+765.811 .093=$ Rp.542.356.493. It can be concluded that this business is feasible, because the NPV is positive.

2. Payaback Period:

Investment $=(223.454 .600)$

Net cash flow/benefitof year $1=\underline{112.300 .000}$

Net cash flow/benefit of year $2=118.490 .600$

The Payback Period is 1 year 11.5 months. If the owner wantsthat his/her capital invested in this business should be back not more than 1 year, 11.5 months, this business is feasible or acceptable.Otherwise, this business is not feasible or unacceptable.

3. Average rate of Return:

The average profit earned Rp696.931.680/5 $=\mathrm{Rp} 193.862 .536$. Average Investment is 101229600-1.295.200/2 =Rp. 49.967.200 + Rp.122.225.000 = Rp.127.221.700.

$A R R=193.862 .536 / 127.221 .700=1.52(152 \%)$. If the owner wants that the ARR is not less than $100 \%$, this business is obviously feasible or acceptable.

4. Profitability Index: feasible.

$\mathrm{PI}=540.553 .076 / 223.454 .600=2.44 . \mathrm{PI}$ is higher than 1 ; thus, this business is

\section{CONCLUSION}

From the point of view of market opportunity this busniness is feasible.It is projected increase of consumers by $10 \%$ per year, as well as increase of sales $22.4 \%$, and profit $46.4 \%$ in average per year. Financially, this business is also feasible, either from the point of view of NPV, ARR, PI or Payback Period.

The success of this business, however, is also very depend on the seriousness and work hard, as well as the discipline of the owner and all employees in managing this business. In addition, an external factor, such as the condition of the economy also affects the success of this business. Therefore, the owner needs to be able to read the conditionschanging time by time, in order to be able to adjust the business strategies, so the business is able to survive and making profit.

\section{REFERENCES}

1. Dwi Prastowodan Rifka Julianty.2005. Analisis Laporan Keuangan. Edisi kedua Gramedia. Jakarta: Pustaka Umum.

2. Eve, Christopher (2017), Industri Makanan dan Minuman Kontribusi 31\% Dari PDB Indonesia.www.suara.com/bisnis/2016/09/23/230957/

3. Fraser. Lyn M dan Aileen Ormiston. 2008. Memahami Laporan Keuangan. Jakarta: PT. 
Indeks.

4. Henry, Simamora. 2006. Akuntansi Basis Pengambilan Keputusan Bisnis. Jakarta: Salemba Empat.

5. Hermawan, Francisca; Petrus PiusPius; Meiliana, Analis SWOT, Bisnis Model Kanvas, dan Kelayakan Keuangan Studi Kasus Bisnis Amigurumi M's Crochet, Jurnal Ekonomi\& Pembangunan, Optimum, Vol.7, No. 2, tahun 2017.

6. Husnan, Suad; Sarwono Muhammad, Studi Kelayakan Proyek, edisi kelima, UPP STIM,YKPN Yogyakarta,2014.

7. Jumingan (2009), STUDI KELAYAKAN BISNIS Teori \& Pembuatan Proposal Kelayakan, Jakarta, Bumi Aksara 2009.

8. Kieso, Weygandt dan Warfield. 2007. Intermediate Accounting, Twelfth Edition. Jakarta: Erlangga.

9. Kotler, P., \& Amstrong, G. (2009). Marketing Management $\left(13^{\text {th }}\right.$ e.). Upper Saddle River, N.J: Pearson Pretince Hall.

10. Lind, Douglas A., William G. Marchal, and Samuel A. Wathen. (2015). Statistical Techniques in Business \& Economics, $16^{\text {th }}$ edition. USA: McGraw-Hill Education.

11. Mamduh, M. Hanafi dan Abdul Halim. 2003. Analisis Laporan Keuangan. Yogyakarta: UPP AMP YPKN.

12. Miller, Michael (2008), Alpha Teach Yourself: Business Plans dalam 24 jam, ed.1, Jakarta, Prenada 2008.

13. Nazir, Muhammad. 2003. Metode Penelitian. Jakarta: Ghalia Indonesia.S. Munawir. 2004. Analisis Laporan Keuangan, Edisi Empat. Yogyakarta: PT. Liberty.

14. Ramdhan, H.E. (2016). Startupreneur - Menjadi Entrepreneur Startup. Jakarta: Penebar Plus.

15. Robbins, S.P., \& Coutler, M. (2010). Manajemen. Jakarta: Penerbit Erlangga.

16. Salamin, Petrus; Francisca Hermawan; Purnama Putri Sari, Analisis Bisnis Model Kanvas dan Kelayakan Keuangan (Studi Kasus Pada Teri Sambal Terateri), Jurnal Manajemen \& Bisnsis SriwijayaVol.15, tahun 2017.

17. Santoso, Singgih. 2011. Structural Equation Modeling (Konsep dan Aplikasi dengan AMOS 18). Jakarta: PT. Elex Media Komputindo.

18. Scarborough, Norman M.; Cornwel, Jeffrey R. (2016), Essentials of Entrepreneurship and Small Business Management, Eight Edition, Pearson Education Limited, 2016.

19. Osterwalder, A. and Pigneur, Y. (2015). Business Model Generation. Jakarta: Elex Media Komputindo.

20. Umar, Husein; (2014), Teknik Menganalisis Kelayakan Rencana Bisnis secara Komprehensif, Studi Kelayakan Bisnis, Gramedia Pustaka Utama 2005. 